\title{
Efficacy of Dairy Cattle Slurry in Preventing Zinc Deficiency of a Silage Corn (Zea mays L.) Grown on a Sandy Soil
}

\author{
Saad Drissi ${ }^{1}$, Abdelhadi Aït Houssa ${ }^{2}$, Ahmed Bamouh $^{1}$, El Madani Daoudi ${ }^{3} \&$ Mohamed Benbella $^{2}$ \\ ${ }^{1}$ Plant Production, Protection and Biotechnology Department, Hassan II Agronomy and Veterinary Institute, \\ Rabat, Morocco \\ ${ }^{2}$ Department of Agronomy and Plant Breeding, National Agricultural School of Meknes, Meknes, Morocco \\ ${ }^{3}$ Moroccan Laboratory of Agriculture (LABOMAG), Casablanca, Morocco \\ Correspondence: Saad Drissi, Plant Production, Protection and Biotechnology Department, Hassan II Agronomy \\ and Veterinary Institute, Rabat, Morocco. E-mail: drissi_agro@yahoo.com
}

Received: January 26, 2015 Accepted: February 25, 2015 Online Published: April 15, 2015

doi:10.5539/jas.v7n5p56 URL: http://dx.doi.org/10.5539/jas.v7n5p56

\begin{abstract}
Corn silage (Zea mays L.), grown on sandy soil, was severely affected by Zinc (Zn) deficiency stress. Mineral and organic $\mathrm{Zn}$ sources were required to prevent this deficiency. The objective of this study is to evaluate the effectiveness of dairy cattle (Bos taurus) slurry as an organic source of Zn in preventing $\mathrm{Zn}$ deficiency in corn silage grown on sandy soil. A field experiment was conducted and six rates of dairy cattle slurry were spread just before sowing: 0 or no slurry spread; $50 ; 100 ; 150 ; 200$ and $300 \mathrm{t} \mathrm{ha}^{-1}$. These slurry rates were compared to an adequate mineral $\mathrm{Zn}$ supply of $5 \mathrm{mg} \mathrm{kg}{ }^{-1}$ applied to soil as $\left(\mathrm{ZnSO}_{4} \cdot 7 \mathrm{H}_{2} \mathrm{O}\right)$. Regression analysis has shown that slurry rates ranging between 50 and $60 \mathrm{t} \mathrm{ha}^{-1}$ had almost similar efficacy to the adequate $\mathrm{Zn}$ mineral supply. Both of them corrected $\mathrm{Zn}$ deficiency symptoms, enhanced plant growth and increased silage yield by 37.5\%, compared to no $\mathrm{Zn}$ or slurry applications. A high slurry rate of $280 \mathrm{t} \mathrm{ha}^{-1}$ maximized silage yield but may pose a threat to the environment due to its high content of nitrogen $(\mathrm{N})$. At the next cropping season, a sufficient DTPA residual $\mathrm{Zn}$ soil content of $0.9 \mathrm{mg} \mathrm{kg}^{-1}$ was recorded only with a high slurry rate $\left(300 \mathrm{t} \mathrm{ha}^{-1}\right)$.
\end{abstract}

Keywords: corn silage, zinc deficiency, dairy cattle slurry, Zn mineral, mineral content, growth, yield

\section{Introduction}

$\mathrm{Zn}$ deficiency is a worldwide nutritional constraint that reduces the yield of many crops, especially cereals (Cakmak, 2008). Maize (Zea mays L.) is known to be very sensitive to Zn deficiency (Lindsay \& Norvel, 1977). Under $\mathrm{Zn}$ deficiency stress, maize has shown white bands between the midrib and the margin of leaves (Singh, Natesan, Singh, \& Usha, 2005), accompanied by an obvious decline in plant height (De Vasconcelos, Clístenes, \& Fernando, 2011) and in dry matter production (Van Biljon, Wright, Fouche, \& Botha, 2010). These symptoms are explained by the important physiological functions performed by $\mathrm{Zn}$, which include protein synthesis and energy production (Hansch \& Mendel, 2009). Sandy soils are generally deficient in Zn (Bhupinder, Senthil, Singh, \& Usha, 2005). In this case, an adequate soil $\mathrm{Zn}$ supply as mineral or organic forms can prevent this deficiency (Murphy \& Walsh, 1972). In the context of many dairy farmlands from Loukkos perimeter (North-West of Morocco), corn silage grown on sandy soil has shown clear $\mathrm{Zn}$ deficiency symptoms. Consequently, an important silage yield decline was recorded compared to adequate fertilized plots receiving either Zn mineral supply or farmyard manures. In this regard, Wallingford, Murphy, Powers and Manges (1975) reported that farmyard manures can enhance soil Zn availability. Among farmyard manures applied, dairy cattle slurry is an important effluent of dairy farms. Many studies reported its advantageous effects in improving soil content in macronutrients, micronutrients, organic matter (Nikoli \& Matsi, 2011; Matsi, Lithourgidis, \& Gagianas, 2003), and thereby corn silage yield (Schröder, Ten Holte, \& Brourwer, 1997). In a recent study, Nikoli and Matsi (2011) reported that liquid cattle manure as a source of micronutrients could also indirectly improve the availability of soil native micronutrients through the action of its organic matter. Also, Sinclair and Edwards (2008) reported that cattle slurry contains an amount of $\mathrm{Zn}$ ranging between 11 and $18 \mathrm{~g} \mathrm{t}^{-1}$ (wet weight). On the other hand, Nikoli and Matsi (2011) stated that farmyard manures increased soil content in micronutrients chelated forms, and many authors like Ortega-Blu and Molina-Roco (2007), Chatterjee and Mandal (1985) and Chand, Randhawa, and Bhumbla (1981) reported that Zn chelated forms were more efficient 
than inorganic ones. Still, an over application of farm manures may threaten the environment because of nitrate leaching (Beckwith, Cooper, Smit, \& Shepherd, 1998) and heavy metals accumulation (Berenguer, Cela, Santiveri, Boixadera, \& Lloveras, 2008).

Despite the numerous researches discussing the advantages and disadvantages of farm manures application on soil nutrients enrichment, we find little information about the possibility of substituting $\mathrm{Zn}$ mineral supply either by dairy cattle slurry or by other animal manures. For this reason, the following work aims to compare the effectiveness of dairy cattle slurry rates to an adequate mineral $\mathrm{Zn}$ supply, in terms of preventing $\mathrm{Zn}$ deficiency in corn silage grown on sandy soil.

\section{Method}

\subsection{Site Description}

A field experiment was carried out on an agricultural farm (Bassita II) located in Loukkos perimeter $\left(34^{\circ} 96^{\prime} \mathrm{N}\right.$ lat., $6^{\circ} 21^{\prime} \mathrm{W}$ long., $60 \mathrm{~m}$ above the sea level, North West of Morocco). The climate is maritime. During the growing season (May to August), the average maximum and minimum temperatures were $18.5^{\circ} \mathrm{C}$ and $27.3{ }^{\circ} \mathrm{C}$, respectively. Also, a low precipitation rate $(11 \mathrm{~mm})$ was recorded during this period. A climatic comparison between the studied growing season and the long term climatic data of the last 40 years is provided in Table1.

Table 1. Climatological data of the experimental site during the growing season (May to August) of 2012 and the last 40 years average (1971-2010) *

\begin{tabular}{|c|c|c|c|c|c|c|c|c|}
\hline & \multicolumn{2}{|c|}{ Min temperature $\left({ }^{\circ} \mathrm{C}\right)$} & \multicolumn{2}{|c|}{ Max temperature $\left({ }^{\circ} \mathrm{C}\right)$} & \multicolumn{2}{|c|}{$\begin{array}{l}\text { Evapotranspiration } \\
\left(\mathrm{mm} \mathrm{day}^{-1}\right)\end{array}$} & \multicolumn{2}{|c|}{ Rainfall (mm) } \\
\hline & 2012 & Long term & 2012 & Long term & 2012 & Long term & 2012 & Long term \\
\hline May & 15.54 & 13.76 & 26.32 & 22.24 & 3.64 & 2.75 & 7 & 34.71 \\
\hline June & 18.23 & 16.67 & 27.66 & 25.04 & 4.07 & 3.56 & 0 & 9.17 \\
\hline July & 20.58 & 18.69 & 29.58 & 27.57 & 4.56 & 4.06 & 0 & 0.93 \\
\hline August & 19.93 & 18.94 & 25.70 & 27.57 & 4.02 & 4.09 & 4 & 1.82 \\
\hline
\end{tabular}

*Source: Taken from National Directorate of Meteorology (DMN), Morocco.

\subsection{Soil and Dairy Cattle Slurry Characteristics}

The soil is sandy ( $88.8 \%$ of sand, $7.5 \%$ of clay and $5.3 \%$ of silt), deficient in DTPA extractable Zn with an amount of $0.13 \mathrm{mg} \mathrm{kg}{ }^{-1}$, which was below the critical level of $0.8 \mathrm{mg} \mathrm{kg}^{-1}$ required for corn production (Lindsay \& Norvell, 1977). It's not calcareous $\left(0.1 \%\right.$ of total $\left.\mathrm{CaCO}_{3}\right)$, with a $\mathrm{pH}$ of $6.1\left(\mathrm{soil} / \mathrm{H}_{2} \mathrm{O}\right.$ as $\left.1 / 5\right)$ and a low amount of organic matter $(0.4 \%)$ (Walkley \& Black, 1934). The other chemical properties of soil are presented in Table 2.

Table 2. Soil characteristics

\begin{tabular}{|c|c|}
\hline Soil property & \\
\hline $\mathrm{pH} \mathrm{H}_{2} \mathrm{O}(1 / 5)$ & 6.10 \\
\hline Cation exchange capacity (meq $100 \mathrm{~g}^{-1}$ ) (Cobaltihexamine Chloride method) & 4.40 \\
\hline Organic matter (\%) (Walkley \& Black method) & 0.40 \\
\hline Extractable $\mathrm{P}_{2} \mathrm{O}_{5}\left(\mathrm{mg} \mathrm{kg}^{-1}\right)($ Olsen method $)$ & 49 \\
\hline Extractable $\quad \mathrm{K}_{2} \mathrm{O}\left(\mathrm{mg} \mathrm{kg}^{-1}\right)($ Ammonium Acetate method $)$ & 81 \\
\hline Extractable $\mathrm{MgO}$ ( $\left.\mathrm{mg} \mathrm{kg}^{-1}\right)$ (Ammonium Acetate method) & 101 \\
\hline Extractable $\mathrm{CaO}\left(\mathrm{mg} \mathrm{Kg}^{-1}\right)$ (Sodium Acetate method) & 868 \\
\hline DTPA extractable $\mathrm{Zn}\left(\mathrm{mg} \mathrm{kg}^{-1}\right)$ & 0.13 \\
\hline DTPA extractable Fe $\left(\mathrm{mg} \mathrm{kg}^{-1}\right)$ & 17.45 \\
\hline DTPA extractable Mn $\left(\mathrm{mg} \mathrm{kg}^{-1}\right)$ & 17.40 \\
\hline DTPA extractable $\mathrm{Cu}\left(\mathrm{mg} \mathrm{kg}^{-1}\right)$ & 0.06 \\
\hline
\end{tabular}


The dairy cattle (Bos taurus) slurry used in this experiment was a mixture of feces, urine, feed residue and washing water. It had $79 \%$ of moisture. Its dry matter contained $106.79 \mathrm{mg} \mathrm{kg}^{-1}$ of total $\mathrm{Zn}$ and $1.91 \%$ of total N. The other chemical properties are listed in Table 3.

Table 3. Dairy cattle slurry characteristics

\begin{tabular}{|c|c|c|c|}
\hline \multicolumn{4}{|c|}{ Total mineral content on slurry dry matter } \\
\hline \multicolumn{2}{|c|}{$(\%)$} & \multicolumn{2}{|c|}{$\left(\mathrm{mg} \mathrm{kg}^{-1}\right)$} \\
\hline $\mathrm{N}$ & 1.91 & $\mathrm{Zn}$ & 106.79 \\
\hline $\mathrm{P}$ & 0.52 & $\mathrm{Cu}$ & 19.75 \\
\hline $\mathrm{K}$ & 1.80 & B & 26.49 \\
\hline $\mathrm{Mg}$ & 0.58 & $\mathrm{Mn}$ & 179.95 \\
\hline $\mathrm{Ca}$ & 3.19 & $\mathrm{Fe}$ & 5534.28 \\
\hline $\mathrm{Cl}$ & 0.81 & $\mathrm{Na}$ & 8466.76 \\
\hline \multicolumn{2}{|c|}{ Organic matter $(\%)$} & \multicolumn{2}{|c|}{65.60} \\
\hline \multicolumn{2}{|c|}{$\mathrm{C} / \mathrm{N}$} & \multicolumn{2}{|c|}{19.84} \\
\hline \multicolumn{2}{|c|}{ Moisture content (\%) } & \multicolumn{2}{|c|}{79} \\
\hline
\end{tabular}

\subsection{Crop Management and Experimental Design}

Corn silage cv. Panama was seeded on May 13, 2012 in $45 \mathrm{~cm}$ double rows spacing, $90 \mathrm{~cm}$ between double rows spacing and $12 \mathrm{~cm}$ seed distance to approximate 120,000 plants ha $^{-1}$. The experimental design was a randomized complete block with five replications. The plot size was 4 by $8 \mathrm{~m}$ and contained three double rows. There were 4 $\mathrm{m}$ between adjacent plots in the same block and $1.4 \mathrm{~m}$ between adjacent blocks. Six rates of dairy cattle slurry were tested: $0 ; 50 ; 100 ; 150 ; 200$ and $300 \mathrm{tha}^{-1}$. The slurry rate of $50 \mathrm{tha}^{-1}$ produces a $\mathrm{Zn}$ amount of $1.1 \mathrm{~kg} \mathrm{ha}^{-1}$ and $\mathrm{N}$ amount of $201 \mathrm{~kg} \mathrm{ha}^{-1}$. These slurry treatments were compared to an adequate mineral $\mathrm{Zn}$ supply of

$5 \mathrm{mg} \mathrm{kg}^{-1}$ applied as $\left(\mathrm{ZnSO}_{4} \cdot 7 \mathrm{H}_{2} \mathrm{O} ; 22.5 \%\right.$ of $\left.\mathrm{Zn}\right)$. The mineral $\mathrm{Zn}$ treatment was recognized in a previous study as the optimal supply for corn silage grown on a sandy soil (Drissi, unpublished MA thesis). One day before sowing, the total rates of slurry were spread using a spreading machine. Few hours after, the slurry was incorporated into the soil using a rotavator. Mineral $\mathrm{Zn}$ treatment was applied as a solution of $\mathrm{Zn}$ sulfate in the middle of each double cropping row. It was split at three different times during the growing season: i) $50 \%$ just after sowing, ii) $25 \%$ at $4-5$ leaf stage, and iii) $25 \%$ at $8-9$ leaf stage.

In order to make sure that $\mathrm{Zn}$ was the only nutrient limiting corn silage growth and yield, all treatments were adequately fertilized with $395 \mathrm{Kg} \mathrm{ha}^{-1}$ of $\mathrm{N}$ as ammonium nitrate and diammonium phosphate (DAP), $334 \mathrm{Kg}$ ha $^{-1}$ of $\mathrm{P}_{2} \mathrm{O}_{5}$ as DAP, $33 \mathrm{Kg} \mathrm{ha}^{-1}$ of $\mathrm{K}_{2} \mathrm{O}$ as potassium sulfate, $3.3 \mathrm{Kg} \mathrm{ha}^{-1}$ of Mn as manganese sulfate, $6.2 \mathrm{Kg}$ $\mathrm{ha}^{-1}$ of $\mathrm{Cu}$ as copper sulfate and $4.6 \mathrm{Kg} \mathrm{ha}^{-1}$ of $\mathrm{B}$ as boron sulfate, these amounts were split adequately during the growing season.

Each line of plants was equipped with a drip line irrigation system with $1.2 \mathrm{~L} \mathrm{~h}^{-1}$ emitters and $0.4 \mathrm{~m}$ as emitters spacing. Watering was done whenever required throughout the experiment. In order to control weeds, pre-emergence herbicides (Pendimethaline, Mesotrione, Terbuthylazine and S-metolachlor) were sprayed. Insects (Heliothis, spodoptera and sesamia) were controlled with Indoxocarb and fungal disease (Helmintosporium) was controlled with Epoxiconazole.

\subsection{Measurements}

According to the description of Zn deficiency symptoms in corn reported by many authors (Alloway, 2008; Singh et al., 2005), the evolution of these symptoms was described during the growing season on ten randomly chosen plants for each treatment's replication. Stem height and stem diameter were measured at harvest on ten randomly chosen plants for each treatment's replication. Also, the total leaf area was measured on three randomly chosen plants per each treatment's replication using Formula (1) (Dwyer \& stewart, 1986 in Mokhtarpour et al., 2010):

$$
\text { Total leaf area per plant }=\sum_{n=1}^{n=j}(L \times W \times 0.75)
$$

Where,

$\mathrm{L}, \mathrm{W}$, and $\mathrm{j}$ are leaf length, leaf maximum width, and last leaf of a plant, respectively. 
The harvest was done on August 25, 2012, approximately at a shoot moisture content of 54\%. Ten randomly chosen plants per each treatment's replication were cut close to the soil surface, and the fresh weights of the harvest were measured.

For shoot dry matter partitioning, a subsample of three plants per each replication's treatment was taken and partitioned into leaves, stem, kernels, cob and husks. Then, the plants parts were dried to constant weight. Three randomly chosen ears per each replication's treatment were taken to determine kernels yield components: total number of ovules per ear using Formula (2), pollination rate using Formula (3) and thousand kernels dry weight.

$$
\begin{aligned}
& \text { Total number of ovules per ear }=\text { Number of kernels }+ \text { Number of sterilized ovules } \\
& \text { Pollination rate }=\text { (Number of kernels per ear / Total number of ovules per ear }) \times 100
\end{aligned}
$$

In order to determine corn mineral concentration at harvest, three whole aerial tissues from 0, 100, 200 and $300 \mathrm{t}$ $\mathrm{ha}^{-1}$ of slurry treatments and $\mathrm{Zn}$ mineral supply were dried in an oven at $70{ }^{\circ} \mathrm{C}$ and ground to powder. Thereafter, three subsamples of $2 \mathrm{~g}$ from the three chopped plants, cited above, were digested with a mixture of nitric, perchloric and sulfuric acids to analyze Zn concentration (Chintala et al., 2012a; Chintala et al., 2012b). Three other subsamples of $0.6 \mathrm{~g}$ were digested with a mixture of salicylic and sulfuric acids to analyze $\mathrm{N}, \mathrm{P}, \mathrm{K}, \mathrm{Ca}$ and Mg. K, Ca, Mg and Zn were determined using an atomic absorption spectrophotometer (Varian AA $240 \mathrm{FS}$; air acetylene flame). While a continuous flow analyzer (Skalar San++) was used to determine N and P (Chintala et al., 2013; Chintala et al., 2014). Furthermore, three soil samples $(0-20 \mathrm{~cm}$ depth $)$ from each treatment, except 50 and $150 \mathrm{t} \mathrm{ha}^{-1}$ slurry rates, were sampled at the next growing season. Thereafter, they were ground to pass a 2 $\mathrm{mm}$ sieve then analyzed for available $\mathrm{Zn}$ by DTPA extractant method using the same atomic absorption spectrophotometer.

\subsection{Statistical Analysis}

All data were subjected to the analysis of variance (ANOVA) at $\mathrm{P} \leq 0.05$ level. Regression analysis was applied to evaluate slurry rates, and the best regression lines were fitted using the highest $\mathrm{r}^{2}$. The difference between $\mathrm{Zn}$ mineral supply and dairy cattle manure rates was analyzed using the Dunett test at $\mathrm{P} \leq 0.05$ level. These statistical analyses have been done using the program SPSS (Version 17.0).

\section{Results}

\subsection{Evolution of Visual Zn Deficiency Symptoms}

$\mathrm{Zn}$ deficiency symptoms appeared at an earlier stage (4-5 leaf stage) for all treatments, but the severity of these symptoms was less manifested either with increasing slurry rates or with mineral Zn supply. A clear linear white area between the midrib and the margin of leaves appeared on plants grown without $\mathrm{Zn}$ or slurry applications while some pale green linear stripes were observed with high slurry rates (200-300 $\left.\mathrm{t} \mathrm{ha}^{-1}\right)$. Approximately at 8-9 leaf stage, all treatments showed a clear recovery from $\mathrm{Zn}$ deficiency stress. This recovery capacity manifested itself more and earlier with increasing slurry rates. From anthesis to harvest, all treatments, except for no $\mathrm{Zn}$ or slurry applications, didn't show any Zn deficiency symptoms.

\subsection{Plant Growth}

At harvest, stem height, stem diameter and leaf area showed significant quadratic responses towards slurry rates. Regression analysis showed that slurry rates around $50 \mathrm{tha}^{-1}$ induced similar growth responses to $\mathrm{Zn}$ fertilization. Both of them improved stem height, stem diameter and leaf area approximately by $9 \%, 10 \%$ and $25 \%$, respectively, compared to no Zn or slurry applications (Figures 1A, 1B and 1C). Maximum growth was recorded with high slurry spread between 240 and $300 \mathrm{tha}^{-1}$. It provided an increase that reaches almost $19 \%, 29 \%$ and 92 $\%$ on stem height, stem diameter, and leaf area, respectively. 

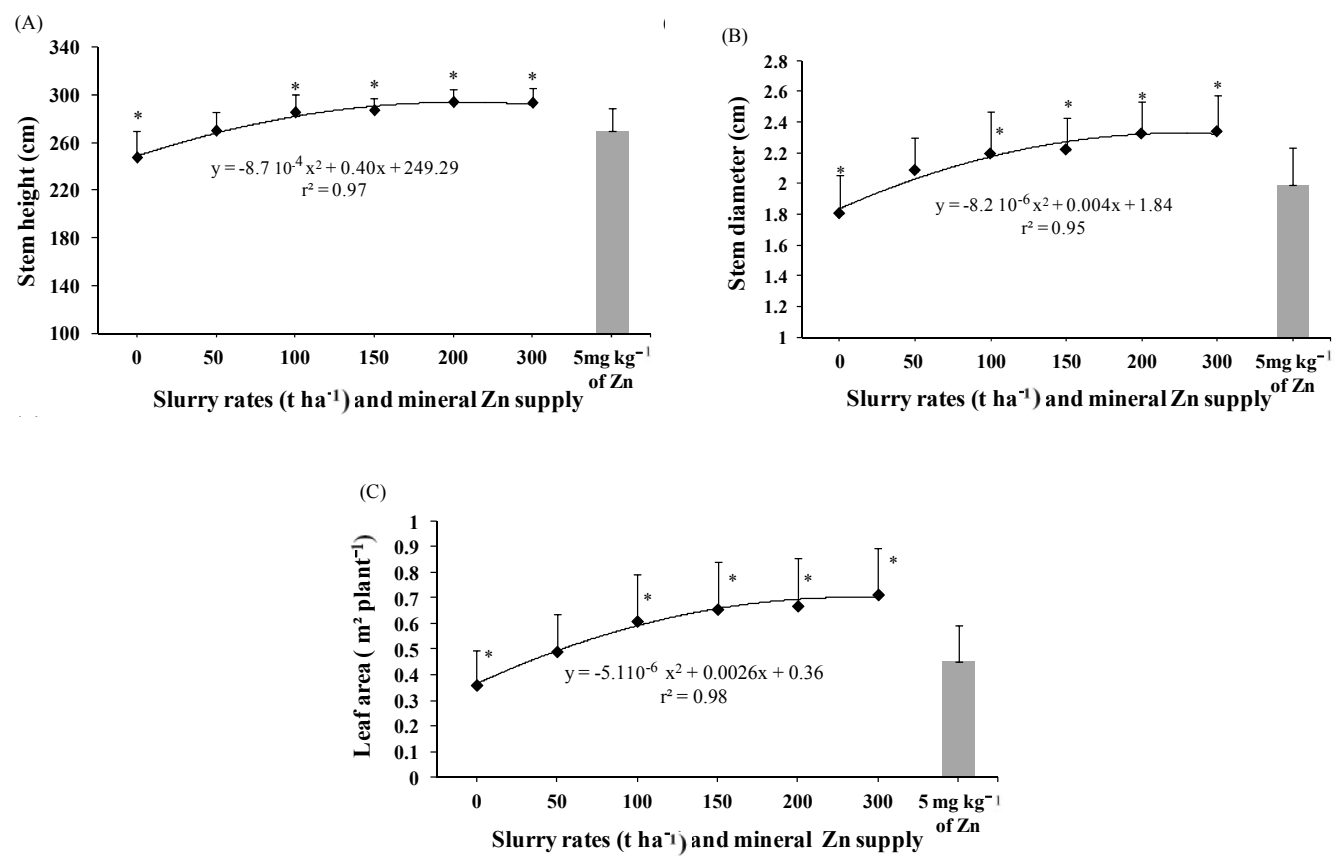

Figure 1. Stem height (A) stem diameter (B) and leaf area (C) of corn silage at harvest following application of dairy cattle slurry rates or mineral $\mathrm{Zn}$. Vertical bars denote standard deviation. ${ }^{*}$ The value differed from $\mathrm{Zn}$ treatment using Dunett test $(\mathrm{p} \leq 0.05)$

\subsection{Silage Yield and Shoot Dry Matter Partitioning}

Dairy slurry or mineral $\mathrm{Zn}$ applications provided a significant rise in silage yield. This latter had quadratic response towards slurry spread. A rate of $63 \mathrm{t} \mathrm{ha}^{-1}$ had similar response to mineral $\mathrm{Zn}$ supply. Both of them induced a silage yield rise of $37.5 \%$ compared to no $\mathrm{Zn}$ or slurry applications (Figure 2). The maximum yield was recorded with high slurry rate of $292 \mathrm{t} \mathrm{ha}^{-1}$, which induced an increase of $94.78 \%$ compared to no $\mathrm{Zn}$ or slurry applications.

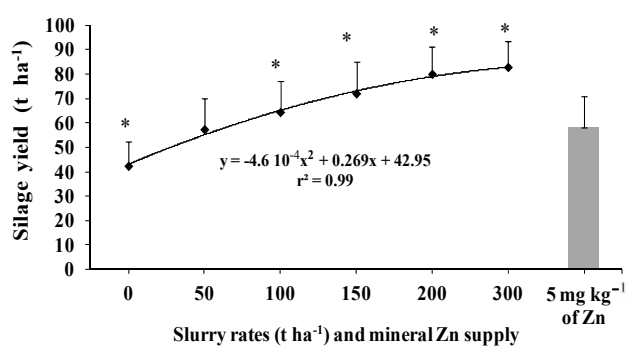

Figure 2. Corn silage yield following application of dairy cattle slurry rates or mineral Zn. Vertical bars denote standard deviation. * The value differed from $\mathrm{Zn}$ treatment using Dunett test $(\mathrm{p} \leq 0.05)$

Through the analysis of shoot dry matter partitioning, we noted that leaves, stem and ears dry weights increased significantly with the addition of slurry or $\mathrm{Zn}$ (Figure $3 \mathrm{~A}$ ). $50 \mathrm{tha}^{-1}$ of slurry or $\mathrm{Zn}$ supply provided increases of approximately $28.4 \%, 37 \%$ and $10.5 \%$ on ear, stem and leaves dry weights, respectively, compared to no $\mathrm{Zn}$ or slurry applications. These increases were approximately of $43.9 \% ; 101 \%$ and $82.5 \%$, respectively, from slurry rate of $150 \mathrm{t} \mathrm{ha}^{-1}$. The ear biomass partitioning analysis showed that kernels, husks and cob dry weights responded significantly to slurry and $\mathrm{Zn}$ treatments (Figure 3B). Compared to no $\mathrm{Zn}$ or slurry applications, $\mathrm{Zn}$ supply resulted in kernels dry weight rise of $31.2 \%$, which was similar to the increase achieved with slurry spread of $50 \mathrm{tha}^{-1}$ while slurry application of $50 \mathrm{t} \mathrm{ha}^{-1}$ provided an increase of approximately $47.5 \%$. Husks and cob dry weights showed significant increases of $35.1 \%$ and $36.3 \%$, respectively, either with slurry or $\mathrm{Zn}$ applications. 

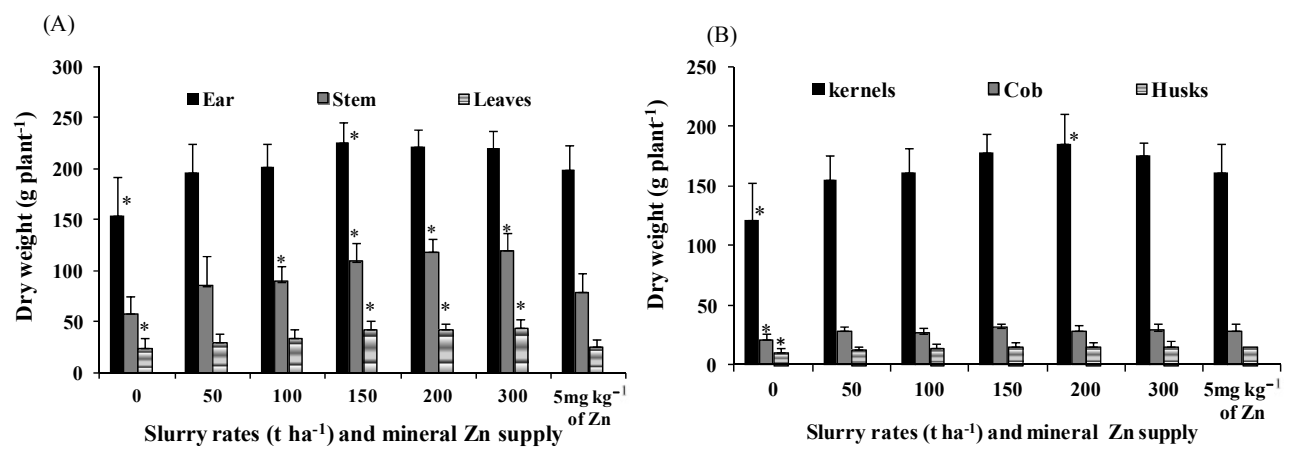

Figure 3. Shoot dry weight partitioning on different plant parts of corn silage (A and B) following application of dairy cattle slurry rates or mineral $\mathrm{Zn}$. Vertical bars denote standard deviation. * The value differed from $\mathrm{Zn}$ treatment using Dunett test $(\mathrm{p} \leq 0.05)$

In order to explain the kernels dry weight response, different kernels yield components were measured. No significant difference in the total number of ovules per ear was noted between different treatments (Figure 4A). However, the pollination rate was significantly enhanced by $7.2 \%$ with all slurry or mineral $\mathrm{Zn}$ applications (Figure 4B). The thousand kernels dry weight significantly improved; $\mathrm{Zn}$ or slurry rate of $68 \mathrm{tha}^{-1}$ induced an increase of $15.1 \%$ compared to no $\mathrm{Zn}$ or slurry applications while high slurry rate of $255 \mathrm{t} \mathrm{ha}^{-1}$ resulted in the highest rise of $25.7 \%$ (Figure $4 \mathrm{C}$ ).
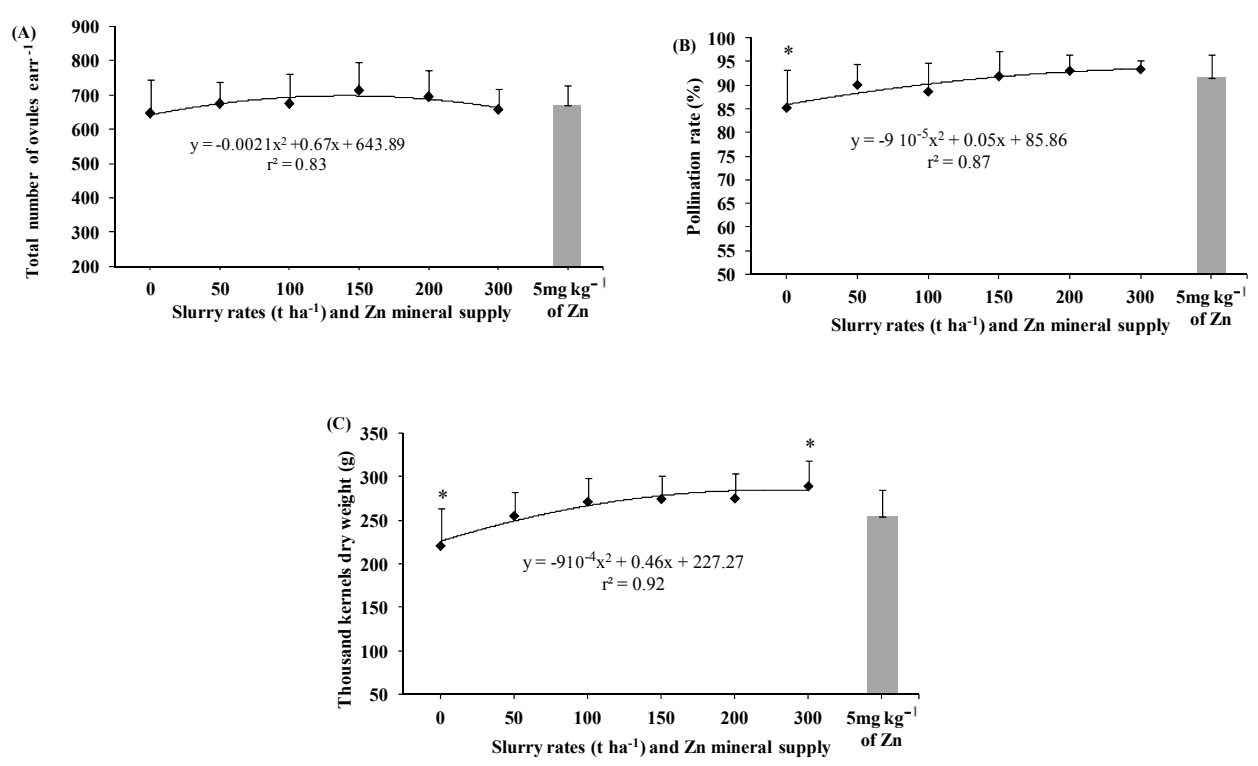

Figure 4. Number of ovules per ear (A), pollination rate (B) and thousand kernels dry weight (C) of corn silage following application of dairy cattle slurry rates or mineral $\mathrm{Zn}$. Vertical bars denote standard deviation. * The value differed from $\mathrm{Zn}$ treatment using Dunett test $(\mathrm{p} \leq 0.05)$

\subsection{Mineral Shoot Content at Harvest}

\subsubsection{Shoot Zn Content}

$\mathrm{Zn}$ deficient plants (no $\mathrm{Zn}$ or slurry applications) had low shoot $\mathrm{Zn}$ content at harvest $\left(16 \mathrm{mg} \mathrm{kg}^{-1}\right)$. This content increased significantly either with slurry or $\mathrm{Zn}$ applications (Figure 5). We recorded the highest concentration of $31.67 \mathrm{mg} \mathrm{kg}^{-1}$ with $\mathrm{Zn}$ supply. Slurry rate of $63 \mathrm{t} \mathrm{ha}^{-1}$, which induced similar yield to $\mathrm{Zn}$ fertilization, had a content of $18.60 \mathrm{mg} \mathrm{kg}^{-1}$ while a high amount of slurry $200-300 \mathrm{t} \mathrm{ha}^{-1}$, which maximized yield, had a $\mathrm{Zn}$ content of around $22 \mathrm{mg} \mathrm{kg}^{-1}$. 


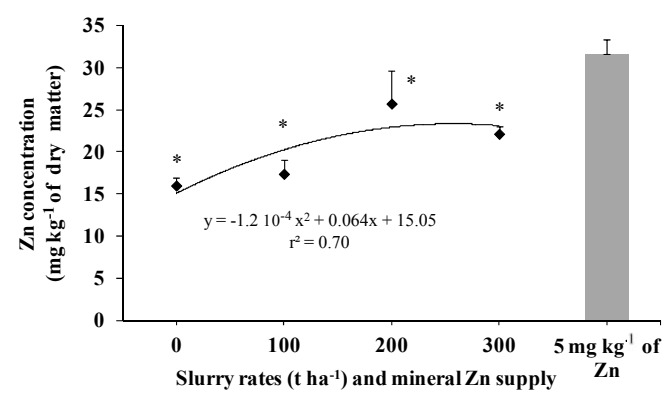

Figure 5. Shoot $\mathrm{Zn}$ concentration in corn silage at harvest following application of dairy cattle slurry or mineral $\mathrm{Zn}$ supply. Vertical bars denote standard deviation. * The value differed from $\mathrm{Zn}$ treatment using Dunett test $(\mathrm{p} \leq 0.05)$

\subsubsection{Shoot Content on N, P, K, Ca and Mg}

High slurry rates (200-300 $\mathrm{tha}^{-1}$ ) resulted in a slightly significant increase in $\mathrm{N}$ and $\mathrm{k}$ shoot content compared to other treatments. They had $\mathrm{N}$ and $\mathrm{K}$ shoot contents around $1.1 \%$ and $0.92 \%$, respectively. Under low slurry rates or $\mathrm{Zn}$ supply, these contents were around $0.96 \%$ and $0.70 \%$, respectively. The $\mathrm{P}, \mathrm{Ca}$, and $\mathrm{Mg}$ shoot concentration, even if they were significantly enhanced with slurry rates, stay around $0.24 \%, 0.13 \%$ and $0.09 \%$, respectively, for all treatments (Table 4).

Table 4. Macronutrients concentration (\% of shoot dry matter) on corn silage at harvest following applications of dairy cattle slurry spread $\left(\mathrm{t} \mathrm{ha}^{-1}\right)$ or mineral $\mathrm{Zn}$ supply

\begin{tabular}{llllll}
\hline & $\mathrm{N}$ & $\mathrm{P}$ & $\mathrm{K}$ & $\mathrm{Ca}$ & $\mathrm{Mg}$ \\
\hline 0 & $0.96 \pm 0.05$ & $0.25 \pm 0.01^{*}$ & $0.71 \pm 0.03$ & $0.07 \pm 0.02^{*}$ & $0.14 \pm 0.01$ \\
100 & $0.99 \pm 0.01$ & $0.24 \pm 0.00^{*}$ & $0.78 \pm 0.01^{*}$ & $0.07 \pm 0.02^{*}$ & $0.13 \pm 0.01^{*}$ \\
200 & $1.14 \pm 0.01^{*}$ & $0.23 \pm 0.00^{*}$ & $0.91 \pm 0.01^{*}$ & $0.09 \pm 0.02$ & $0.11 \pm 0.00^{*}$ \\
300 & $1.13 \pm 0.11^{*}$ & $0.24 \pm 0.01^{*}$ & $0.93 \pm 0.01^{*}$ & $0.10 \pm 0.02$ & $0.12 \pm 0.01^{*}$ \\
\hline $5 \mathrm{mg} \mathrm{kg}^{-1}$ of $\mathrm{Zn}$ & $0.95 \pm 0.00$ & $0.27 \pm 0.00$ & $0.66 \pm 0.03$ & $0.13 \pm 0.01$ & $0.16 \pm 0.01$ \\
\hline F test & + & + & + & + & + \\
\hline
\end{tabular}

Note. Data are the means \pm standard deviation. * The value differed from $\mathrm{Zn}$ treatment using Dunett test $(\mathrm{p} \leq$ $0.05)$.

\subsection{Soil Extractable Residual Zn}

Soil analysis at the next cropping season showed a significant increase in residual DTPA extractable Zn either with addition of slurry or Zn (Figure 6). Slurry application of $300 \mathrm{t} \mathrm{ha}^{-1}$ induced the highest DTPA extractable $\mathrm{Zn}$ of $0.96 \mathrm{mg} \mathrm{kg}^{-1}$ while mineral $\mathrm{Zn}$ supply provided an amount of $0.26 \mathrm{mg} \mathrm{kg}^{-1}$.

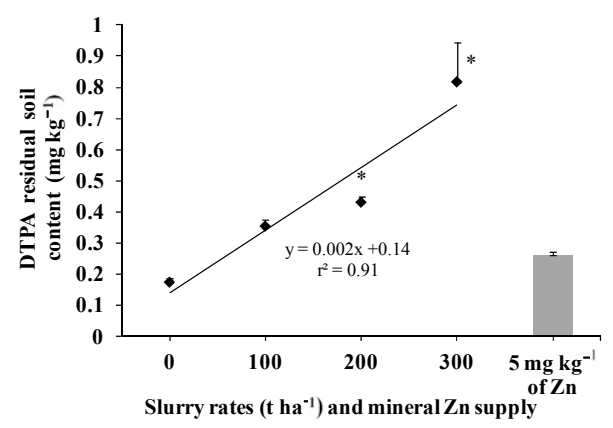

Figure 6. Residual soil DTPA extractable Zn, following application of dairy slurry or mineral Zn, in the next cropping season. Vertical bars denote standard deviation. * The value differed from $\mathrm{Zn}$ treatment using Dunett test $(\mathrm{p} \leq 0.05)$ 


\section{Discussion}

Based on this investigation, slurry spread can substitute $\mathrm{Zn}$ mineral supply to prevent $\mathrm{Zn}$ deficiency on corn silage grown on sandy soil. Slurry rates between 50 and $60 \mathrm{t} \mathrm{ha}^{-1}$ showed similar growth and yield to the adequate $\mathrm{Zn}$ mineral supply.

\subsection{Zn Deficiency Symptoms}

The appearance of $\mathrm{Zn}$ deficiency symptoms is especially due to the low $\mathrm{Zn}$ content of soil $0.13 \mathrm{mg} \mathrm{kg}^{-1}$, which was below the critical level required for corn production $0.8 \mathrm{mg} \mathrm{kg}^{-1}$ (Lindsay \& Norvel, 1977). Their appearance at an earlier stage was already reported by other authors (Wang \& Jin, 2007; Kuldeep \& Banerjee, 1986). The obvious decline of $\mathrm{Zn}$ deficiency symptoms with slurry application, as well as mineral $\mathrm{Zn}$ supply, proved the role of dairy slurry in preventing $\mathrm{Zn}$ deficiency.

\subsection{Plant Mineral Content and Growth}

Shoot $\mathrm{Zn}$ content was enhanced with the addition of slurry as well as Zn supply. Sufficient $\mathrm{Zn}$ content, $22 \mathrm{mg}$ $\mathrm{kg}^{-1}$ (Singh et al., 2005), was recorded either with slurry rates up or equal to $150 \mathrm{t} \mathrm{ha}^{-1}$ or with mineral $\mathrm{Zn}$ supply. $\mathrm{Zn}$ concentration didn't reach Zn phytotoxic concentration, above $95 \mathrm{mg} \mathrm{kg}^{-1}$ (Gupta, Kening, \& Siyuan, 2008), despite high slurry rates. On the other hand, even if slurry rates around $50 \mathrm{t} \mathrm{ha}^{-1}$ didn't increase shoot $\mathrm{Zn}$ content to reach sufficient level, we observed an obvious correction of $\mathrm{Zn}$ deficiency symptoms. The beneficial effects of other nutrients supplied by slurry cannot be excluded even if all treatments had received adequate mineral fertilization of macro and micro nutrients. But, such effects remain weak compared to our limited and controlled nutrient factor of $\mathrm{Zn}$. In fact, plants with $\mathrm{Zn}$ mineral supply had approximately similar shoot content of $\mathrm{N}, \mathrm{P}, \mathrm{Mg}$, and $\mathrm{Ca}$ as slurry treatments. For all these treatments, we recorded that shoot $\mathrm{N}$ content $(\approx 0.95 \%)$ was approximately equal to the required level of corn at maturity (1\%) (Fageria, Baligar, \& Jones, 2011). Also, shoot P content $(\approx 0.24 \%$ ) was around the required level ranging between $0.1 \%$ and $0.5 \%$ (Arnon, 1975 ), and the shoot Mg concentration $(\approx 0.13 \%$ ) was around the adequate concentration of $0.2 \%$ (Fox \& Piekielek, 1984). Although the increase of shoot $\mathrm{K}$ content was recorded with high slurry rates $\left(200-300 \mathrm{t} \mathrm{ha}^{-1}\right)$, all treatments had contents around the required level (between $0.7 \%$ and $0.9 \%$ ) (Arnon, 1975), and no K deficiency symptoms were noticed. Plant growth was enhanced either with slurry or Zn application. The effect of $\mathrm{Zn}$ on stem stretching can be explained by the role of $\mathrm{Zn}$ in the metabolism of indole-acetic acid (IAA) as a growth regulator enzyme (Cakmak, Marshner, \& Bangerth, 1988). Also, the leaf area and stem diameter were also enhanced. A significant increase of leaf area due to $\mathrm{Zn}$ fertilization was noted on corn by Chaab, Savaghebi, Gh, and Motesharezadeh (2011) and on wheat by Khan, Fuller, and Baloch (2008).

\subsection{Silage Yield and Dry Matter Partitioning}

Silage yield improved either with slurry or Zn applications. $63 \mathrm{t} \mathrm{ha}^{-1}$ of slurry resulted in similar yield to the adequate $\mathrm{Zn}$ mineral supply. Such slurry rate brought a $\mathrm{Zn}$ amount of $1.40 \mathrm{~kg} \mathrm{ha}^{-1}$ which was lower than the adequate $\mathrm{Zn}$ mineral supply $\left(20.25 \mathrm{~kg} \mathrm{ha}^{-1}\right)$. This result proved that the effectiveness of $\mathrm{Zn}$ contained in slurry is higher than the mineral one. We may explain that by the fact that $\mathrm{Zn}$ organic forms, contained in slurry, are more efficient than Zn mineral compounds (Ortega-Blu \& Molina-Roco, 2007; Chatterjee \& Mandal, 1985; Chand et al., 1981). This also can be explained by the enhancement of soil born $\mathrm{Zn}$ availability through the action of organic matter (Nikoli \& Matsi, 2011). On the other hand, maximum silage yield was recorded with high slurry rate of $292 \mathrm{t} \mathrm{ha}^{-1}$. This result is consistent with earlier studies of Sutton, Nelson, Kelly and Hill (1986), who reported that liquid dairy manure rate of $224 \mathrm{t} \mathrm{ha}^{-1}$ maximized corn yields. Also, Schröder and Dilz (1987) showed that maize forage yield was promoted with cattle slurry application up to 200-300 $\mathrm{tha}^{-1}$. However, such rate brought an over amount of $\mathrm{N}\left(1171 \mathrm{~kg} \mathrm{ha}^{-1}\right)$ which may threaten the environment through nitrate leaching. In this context, the nitrate directive of the European Union stated that animal manure application, for a given year, must be around an equivalent amount of $170-210 \mathrm{~kg}$ on N ha ${ }^{-1}$ (European Union, 1991). The biomass weight decline under Zn deficiency (no slurry or Zn applications) can partially be attributed to limited photosynthesis rate (Hansch \& Mendel, 2009) due to both disruption in carbonic anhydrase enzyme activity (Sasaki, Hirose, Watanabe, \& Ohsugi, 1998) and chlorophyll synthesis (Cakmak \& Marshner, 1993).

The dry matter partitioning analysis showed that enhancement of silage yield due to addition of slurry or Zn was mainly attributed to the increase of stem and kernels dry weights. Lithourgidis, Matsi, Barbayiannis and Doras (2007) reported that liquid cattle manure enhanced silage and kernels maize yields. The kernels dry matter, which represented about $50 \%$ of shoot dry weight (Figure 2), was mainly enhanced by two components: pollination rate and thousand kernels dry weight. A similar result was reported under $\mathrm{Zn}$ foliar spray on corn silage grown on Zn deficient sandy soil (Drissi, Ait Houssa, Bamouh, \& Benbella, 2015). Under Zn deficiency, the pollination rate decline can be explained by mal sterility (Sharma, Chatterjee, \& Saharma, 1990) while the 
decrease of thousand kernels weight could be attributed to the photosynthesis decline mentioned above.

\subsection{Residual Soil DTPA Extractable Zn}

Soil analysis at the next cropping season showed that slurry improved residual DTPA extractable Zn, but only high rate $\left(300 \mathrm{t} \mathrm{ha}^{-1}\right)$ resulted in sufficient residual amount of $0.92 \mathrm{mg} \mathrm{kg}^{-1}$, which was above the critical level of $0.83 \mathrm{mg} \mathrm{kg}^{-1}$ required for corn (Lindsay \& Norvell, 1977). The $\mathrm{Zn}$ soil enrichment due to slurry spread can be explained by its role as a source of Zn, and by its organic matter's role in releasing native soil Zn (Nikoli \& Matsi, 2011).

\section{Conclusion}

A dairy cattle slurry rate ranging between 50 and $60 \mathrm{tha}^{-1}$ prevented $\mathrm{Zn}$ deficiency and showed similar plant growth and silage yield as the adequate mineral $\mathrm{Zn}$ supply $\left(5 \mathrm{mg} \mathrm{kg}^{-1}\right.$ of $\mathrm{Zn}$ as $\left.\mathrm{ZnSO}_{4} \cdot 7 \mathrm{H}_{2} \mathrm{O}\right)$. High dairy slurry rates $\left(200\right.$ and $\left.300 \mathrm{t} \mathrm{ha}^{-1}\right)$ maximized yield but brought an over amount of $\mathrm{N}$ which may pose a threat to the environment.

\section{Acknowledgements}

The authors would like to think Mr. Loultiti M. M. and Mr. Coquant J. M. for their financial support. We are grateful to Pr. Maataoui A. and Pr. El Midaoui M. for their valuable help during manuscript preparation. We acknowledge the contribution of Mrs. Mouhtadi R., Mrs. Zehri B., Mr. Ziti S., Mr. Soulaimani A., and Mr. Touhami D. during laboratory analysis. Special appreciation is expressed to Mr. Belbassri M. for his cooperation in conducting the experiment. Also, we address our acknowledgements to Dr. Yachoulti M. and Mr. El Gharradi Y. for language correction.

\section{References}

Alloway, J. B. (2008). Zinc in soils and crop nutrition (2nd ed.). International Zinc Association Communications. IZA Publications, Brussel. Retrieved from http://www.zinc.org/general/Zinc_in_Soils_and_Crop_Nutrition ALLOWAY.pdf

Arnon, I. (1975). Mineral nutrition of maize. International Potash Institute, Bern. Retrieved from http://www.ipipotash.org/udocs/mineral_nutrition_of_maize.pdf

Beckwith, C. P., Cooper, J., Smith, K. A., Shepherd, M. A. (1998). Nitrate leaching loss following application of organic manures to sandy soils in arable cropping. I. Effects of application time, manure type, overwinter crop cover and nitrification inhibition. Soil Use and Management, 14, 123-130. http://dx.doi.org10.1111/j.1475-2743.1998.tb00135.x

Berenguer, P., Cela, S., Santiveri, F., Boixadera, J., \& Lloveras, J. (2008). Copper and Zinc Soil Accumulation and Plant Concentration in Irrigated Maize Fertilized with Liquid Swine Manure. Agronomy Journal, 100, 1056-1061. http://dx.doi.org/10.2134/agronj2007.0321

Bhupinder, S., Senthil, K. A. N., Singh, B. K., \& Usha, K. (2005). Improving zinc efficiency of cereals under zinc deficiency. Current Science, 88, 36-44. Retrieved from http://eprints.icrisat.ac.in/46/

Cakmak, I. (2008). Enrichment of cereal grains with zinc: Agronomic or genetic biofortification? Plant and Soil, 302, 1-17. http://dx.doi.org/10.1007/s11104-007-9466-3

Cakmak, I., \& Marshner, H. (1993). Effect of zinc nutritional status on activities of superoxide radical and hydrogen peroxide scavenging enzymes in bean leaves. Plant and Soil, 155-156, 1127-1130. http://dx.doi.org/10.1007/BF00025000

Cakmak, I., Marshner, H., \& Bangerth, F. (1988). Effect of zinc nutritional status on growth, protein metabolism and levels of indole 3 acetique acid and other phytohormones in bean (Phaseolus vulgaris). Journal of Experimental Botany, 40, 405-412. http://dx.doi.org/10.1093/jxb/40.3.405

Chaab, A., Savaghebi, Gh. R., \& Motesharezadeh, B. (2011). Differences in the zinc efficiency among and within maize cultivars in a calcareous soil. Asian Journal of Agricultural Sciences, 3, 26-31. Retrieved from http://www.maxwellsci.com/print/ajas/v3-26-31.pdf

Chand, M., Randhawa, N. S., \& Bhumbla, D. R. (1981). Effectiveness of zinc chelates in zinc nutrition of greenhouse rice crop in a saline-sodic soil. Plant and Soil, 59, 217-225. http://dx.doi.org/10.1007/BF02184195

Chatterjee, A. K., \& Mandal, L. N. (1985). Zinc sources for rice in soil at different moisture regimes and organic matter levels. Plant and Soil, 87, 393-404. http://dx.doi.org/10.1007/BF02184195 
Chintala, R., McDonald, L. M., \& Bryan, W. B. (2012a). Effect of soil water and nutrients on productivity of Kentucky blue grass systems in acidic soils. Journal of Plant Nutrition, 35, 288-303. http://dx.doi.org/10.1080/01904167. 2012.636131

Chintala, R., McDonald, L. M., \& Bryan, W. B. (2012b). Optimization of water potential and nutrient levels for Kentucky bluegrass-white clover mixture on acidic soils. Biotechnology, Agronomy, Society and Environment, 16, 167-177. Retrieved from http://www.popups.ulg.ac.be/1780-4507/index.php?id=8619

Chintala, R., Mollinedo, J., Schumacher, T. E., Malo, D. D., Papiernik, S., Clay, D. E., ... Gulbrandson, D. W. (2013). Nitrate sorption and desorption in biochars from fast pyrolysis. Microporous and Mesoporous Materials, 179, 250-257. http://dx.doi.org/10.1016/j.micromeso.2013.05.023

Chintala, R., Schumacher, T. E., McDonald, L. M., Clay, D. E., Malo, D. D., Clay, S. A., ... Julson, J. L. (2014). Phosphorus sorption and availability in biochars and soil biochar mixtures. CLEAN-Soil Air Water, 42(5), 626-634. http://dx.doi.org/10.1002/clen.201300089

De Vasconcelos, A. C. F., Clístenes, W. A. N., \& Fernando, F. C. F. (2011). Distribution of zinc in maize plants as a function of soil and foliar $\mathrm{Zn}$ supply. International Research Journal of Agricultural Science, 1, 1-5. Retrieved from http://interesjournal.org/IRJAS/Pdf/2011/March/de\%20Vasconcelos\%20et\%20al.pdf

Drissi, S., Aït Houssa, A., Bamouh, A., \& Benbella, M. (2015). Corn silage (Zea mays L.) response to zinc foliar spray concentration when grown on sandy soil. Journal of Agricultural Science, 7, 68-79 http://dx.doi.org/10.5539/jas.v7n2p68

European Union. (1991). Council directive 91/676/EEC of 12 December concerning the protection of waters against pollution caused by nitrates from agricultural sources. Official Journal of the European Communities, L375. Brussels, Belgium. Retrieved from http://eur-lex.europa.eu/legal-content/EN/TXT/PD $\mathrm{F} /$ ?uri=OJ:L:1991:375:FULL\&from=EN

Fageria, N. K., Baligar, V. C., \& Jones C. A. (Eds.). (2011). Growth and mineral nutrition of field crops (3rd ed.). Taylor and Francis Group.

Fox, R. H., \& Piekielek, W. P. (1984). Soil magnesium level, corn (Zea mays L.) yield, and magnesium uptake. Communications in Soil Science and Plant Analysis, 15, 109-123. http://dx.doi.org/10.1080/00103628409367459

Gupta, U. C., Kening, W. U., \& Siyuan, L. (2008). Micronutrients in soils, crops, and livestock. Earth Science Frontiers, 15, 110-125. http://dx.doi.org/10.1016/S1872-5791(09)60003-8

Hansch, R., \& Mendel, R. R. (2009). Physiological functions of mineral micronutrients (Cu, Zn, Mn, Fe, Ni, Mo, B, Cl). Current Opinion in Plant Biology, 12, 259-266. http://dx.doi.org/10.1016/j.pbi.2009.05.006

Khan, M. A., Fuller, M. P., \& Baloch, F. S. (2008). Effect of soil applied zinc sulphate on wheat (Triticum aestivum L.) grown on a calcareous soil in Pakistan. Cereal Research Communications, 36, 571-582. http://dx.doi.org/10.1556/CRC.36.2008.4.6

Kuldeep, S., \& Banerjee, N. K. (1986). Growth and zinc content of maize (Zea mays L.) as related to soil-applied zinc. Field Crops Research, 13, 55-61. http://dx.doi.org/10.1016/0378-4290(86)90007-9

Lindsay, W. L., \& Norvell, W. A. (1977). Development of a DTPA soil test for zinc, iron, manganese, and copper. Soil Science Society of America Journal, 42, 421-428. http://dx.doi.org/\%2010.2136/sssaj1978.03615995004200030009x

Lithourgidis, A. S., Matsi, T., Barbayiannis, N., \& Doras, C. A. (2007). Effect of liquid cattle manure on corn yield, composition, and soil properties. Agronomy Journal, 99, 1041-1047. http://dx.doi.org/10.2134/agronj2006.0332

Matsi, T., Lithourgidis, A. S., \& Gagianas, A. A. (2003). Effects of injected liquid cattle manure on growth and yield of winter wheat and soil characteristics. Agronomy Journal, 95, 592-596. http://dx.doi.org/10.2134/agronj2003.0592

Mokhtarpour, H., Teh, C. B. S., Saleh, G., Selamat, A. B., Asadi, M. E., \& Kamkar, B. (2010). Non destructive estimation of maize leaf area, fresh weight, and dry weight using leaf length and leaf width. Communications in Biometry and Crop Science, 5, 19-26. Retrieved from http://agrobiol.sggw.waw.pl/ cbcs/articles/CBCS_5_1_4.pdf

Murphy, L. S., \& Walsh, L. M. (1972). Correction of micronutrients deficiencies with fertilizers. In J. J. Mortvedt, P. M. Giordano \& W. L. Lindsay (Eds.), Micronutrients in Agriculture, Soil Science Society of 
America (pp. 371-381). Retrieved from https://dl.sciencesocieties.org/publications/books/pdfs/sssabook series/micronutrientsi2/frontmatter

Nikoli, T., \& Matsi, T. (2011). Influence of liquid cattle manure on micronutrients content and uptake by corn and their availability in a calcareous soil. Agronomy Journal, 103, 113-118. http://dx.doi.org/10.2134/agronj2010.0273

Ortega-Blu, R., \& Molina-Roco, M. (2007). Comparison between sulfates and chelated compounds as sources of zinc and iron in calcareous soils. Agrociencia, 41, 491-502. Retrieved from http://www.colpos.mx/agrocien/Bimestral/2007/jul-ago/art-1.pdf

Sasaki, H., Hirose, T., Watanabe, Y., \& Ohsugi, R. (1998). Carbonic anhydrase activity and $\mathrm{CO}_{2}$ transfer resistance in $\mathrm{Zn}$ deficient rice leaves. Plant Physiology, 118, 929-934. http://dx.doi.org/10.1104/pp.118.3.929

Schröder, J. J., Ten Holte, L., \& Brourwer, G. (1997). Response of silage maize to placement of cattle slurry. Netherlands Journal of Agricultural Science, 45, 249-261. Retrieved from https://library.wur.nl/ojs/index.php/njas/article/view/516/230

Schröder, J., \& Dilz, K. (1987). Cattle slurry and farmyard manure as fertilizers for forage maize. In H. G.Van Der Meer, R. J. Unwin, T. A. Van Dijk \& G. C. Ennik (Eds.), Animal manure on grassland and fodder crops: Fertilizer or waste? Developments in Plant and Soil Sciences (Vol. 30, pp. 137-156). http://dx.doi.org/10.1007/978-94-009-3659-1_9

Sharma, P. N., Chatterjee, A. S. C., \& Saharma, C. P. (1990). Zinc deficiency and pollen fertility in maize (Zea mays). Plant and Soil, 124, 221-225. http://dx.doi.org/10.1007/BF00009263

Sinclair, A. H., \& Edwards, A. C. (2008). Micronutrient deficiency problems in agricultural crops in Europe. In B. J. Alloway (Ed.), Micronutrients deficiencies in global crop production (pp. 225-244). http://dx.doi.org/10.1007/978-1-4020-6860-7_9

Singh, B., Natesan, S. K. A., Singh, B. K., \& Usha, K. (2005). Improving zinc efficiency of cereals under zinc deficiency. Current Science, 88, 36-44. Retrieved from http://www.iisc.ernet.in/currsci/jan102005/36.pdf

Sutton, A. L., Nelson, D. W., Kelly, D. T., \& Hill, D. L. (1986). Comparison of solid vs. liquid dairy manure applications on corn yield and soil composition. Journal of Environmental Quality, 15, $370-375$. http://dx.doi.org/10.2134/jeq1986.00472425001500040010x

Van Biljon, J. J., Wright, C. A., Fouche, D. S., \& Botha, A. D. P. (2010). A new optimum value for zinc in the main maize producing sandy soils of South Africa. South African Journal of Plant and Soil, 27, 252-255. http://dx.doi.org/10.1080/02571862.2010.10639994

Walkley, A., \& Black, I. A. (1934). An examination of the Degtjareff method for determining soil organic matter, and a proposed modification of chromic acid titration method. Soil Science, 37, 29-38. http://dx.doi.org/10.1097/00010694-193401000-00003

Wallingford, G. W., Murphy, L. S., Powers, W. L., \& Manges, H. L. (1975). Effects of beef-feedlot manure and lagoon water on iron, zinc, manganese and copper content in corn and in DTPA soil extracts. Soil Science Society of America Journal, 39, 482-487. http://dx.doi.org/10.2136/sssaj1975.03615995003900030031x

Wang, H., \& Jin, Ji-Y. (2007). Effects of zinc deficiency and drought on plant growth and metabolism of reactive oxygen species in maize (Zea mays L.). Agricultural Sciences in China, 6, 988-995. http://dx.doi.org/10.1016/S1671-2927(07)60138-2

\section{Copyrights}

Copyright for this article is retained by the author(s), with first publication rights granted to the journal.

This is an open-access article distributed under the terms and conditions of the Creative Commons Attribution license (http://creativecommons.org/licenses/by/3.0/). 